\title{
Bioactive Potentials of Cleome viscosa L. Extracts: Dose-mortality, Insect Repellency and Brine Shrimp Lethality
}

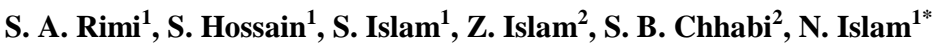 \\ ${ }^{1}$ Department of Zoology, Rajshahi University, Rajshahi 6205, Bangladesh \\ ${ }^{2}$ Department of Genetic Engineering \& Biotechnology, Rajshahi University, Rajshahi 6205, \\ Bangladesh
}

Received 15 May 2017, accepted in final revised form 26 September 2017

\begin{abstract}
Petroleum ether (Pet. ether), chloroform $\left(\mathrm{CHCl}_{3}\right)$ and methanol $\left(\mathrm{CH}_{3} \mathrm{OH}\right)$ extracts of Cleome viscosa have thoroughly screened against Tribolium castaneum (Hbst.) for repellency and dose mortality, against Callosobruchus chinensis for dose mortality activities, and against Artemia salina nauplii for lethality. In case of repellency of $T$. castaneum, Pet. ether extract found significantly active at $1 \%$ level of significance $(\mathrm{P}<$ $0.01), \mathrm{CHCl}_{3}$ extract offered activity at $5 \%$ level of significance $(\mathrm{P}<0.05)$ and $\mathrm{CH}_{3} \mathrm{OH}$ extract did not show any activity at all. In case of mortality against $T$. castaneum the $\mathrm{LD}_{50}$ values of Pet. ether, $\mathrm{CHCl}_{3}$, and $\mathrm{CH}_{3} \mathrm{OH}$ extracts were 2.380, 2.188, 1.867, 1.658 and 1.429 $\mathrm{mg} / \mathrm{cm}^{2} ; 4.950,2.906,2.664,2.658$ and $2.609 \mathrm{mg} / \mathrm{cm}^{2}$; and 4.950 and $2.791,2.609,2.552$ and $2.474 \mathrm{mg} / \mathrm{cm}^{2}$ after $0.5,6,12,18$ and $24 \mathrm{~h}$ of exposure respectively. Against $C$. chinensis the $\mathrm{LD}_{50}$ values of the same extracts were $0.781,0.670,0.642,0.614,0.560$ and $0.494 \mathrm{mg} / \mathrm{cm}^{2} ; 1.964,1.050,0.867,0.725,0.635$ and $0.590 \mathrm{mg} / \mathrm{cm}^{2}$; and $2.631,1.851$, $1.471,1.703,1.524$ and $1.457 \mathrm{mg} / \mathrm{cm}^{2}$ after $6,12,18,24,30$ and $36 \mathrm{~h}$ of exposure respectively. In case of cytotoxicity test against $A$. salina, the extracts offered $\mathrm{LC}_{50}$ values in a descending order $\mathrm{CH}_{3} \mathrm{OH}>\mathrm{CHCl}_{3}>$ Pet. ether extracts.
\end{abstract}

Keywords: Repellency; dose-mortality; cytotoxicity; C. viscosa; T. castaneum; C. chinensis; A. salina.

(C) 2017 JSR Publications. ISSN: 2070-0237 (Print); 2070-0245 (Online). All rights reserved. doi: http://dx.doi.org/10.3329/jsr.v9i4.32592 J. Sci. Res. 9 (4), 375-382 (2017)

\section{Introduction}

C. viscosa L. (Family: Capparacae or Cappardaceae) is an annual sticky herb found as a common weed [1], which is commonly known as 'Asian spider flower', 'Tickweed', 'wild or dog mustard' and in Bengali it is called "Hul hul" [2,3]. This plant is found in all over the world and widely used as a popular medicinal plant in herbal industry. Also found in

\footnotetext{
*Corresponding author: $\underline{n} \_$islamm@yahoo.com
} 
the plains of Arabia, Egypt, Pakistan, and also in Asia and Africa [4]. This herb grows very well in rainy season with sticky shoot and yellow flowers. The plant is collected from the wild area and used it locally as a food and medicine which is occasionally cultivated in India, where it is achieving popularity as a substitute for cumin [5]. It tests bitter and possesses a sharp mustard-like flavor [6]. The pungent seed can be pickled or used as a mustard substitute. A condiment is made by the juice of this plant [7]; oil obtained from the seeds is used for cooking and also used as a stimulant in food in order to improve the appetite. In Ayurveda, it is used as an anthelmintic, carminative, stimulant and vesicant. The leaves are used as an external application to treat wounds and ulcers. A paste of the root is applied externally in the treatment of earaches [8]. The present investigation was designed to find out the repellent potential of the crude extracts of the test plant species on test organisms, $T$. castaneum, $C$. chinensis and A. salina nauplii. $T$. castaneum (Coleoptera: Tenebrionidae) is a worldwide pest of stored products and of Indo-Australian in origin [9]. It is generally found in granaries, mills, warehouses and live on cracked grain on breakfast food or meal, rice, dried fruit, bleached and unbleached wheat flour, cornmeal, barley flour and oatmeal [10]. The eggs are microscopic and the slender larvae are creamy yellow to light brown in color. The adult is a small reddish-brown beetle. Total life cycle contains subsequently for egg incubation 8.8 days, larval development takes 22-100 days, pupal development 4.5 days, and for reproductive maturation 5-4 days, but these are highly dependent on variation of temperature [11]. C. chinensis (Coleoptera: Chryssomelidae) commonly known as pulse beetle found as pest to many stored legumes [12]. Adults are brown in colour with black and grey patches over the body. It possesses egg, larva, pupa and adult stage in its life cycle. Pulse beetle is one of the most damaging to the stored legumes industry due to their generalized legume diets and wide distribution [13]. A. salina is a species of aquatic crustaceans also known as brine shrimp. An Iranian geographer firstly reported it in Urmia Lake in 982 AD [14]. Artemia populations are found worldwide in inland saltwater lakes, but not in oceans. Artemia are able to avoid cohabiting with most types of predators, such as fish, as they have the ability to live in waters of very high salinity (up to $25 \%$ ) [15]. A female uterus of A. salina may contain up to 200 eggs [16]. Eggs are hatched into nauplii that are about $0.5-0.6 \mathrm{~mm}$ in length. Eggs remain in a dormant state as cyst. These cysts can last for a couple of years, and will hatch when they are placed in saltwater [17].

\section{Materials and Methods}

\subsection{Collection and preparation of test materials}

C. viscosa plants were collected from the University of Rajshahi Campus (Bangladesh) and identified by the Department of Botany, University of Rajshahi where a voucher specimen is kept in the Herbarium. The plant parts (leaves, stem, root, fruit and flower) were collected separately and chopped into small pieces, dried under shade and powered with the help of a hand grinder, weighed and placed in conical flasks to add solvents. Pet. 
ether, $\mathrm{CHCl}_{3}$ and $\mathrm{CH}_{3} \mathrm{OH}$ (Merck, Germany) were used $(200 \mathrm{~g} \times 600 \mathrm{~mL} \times 2$ times) successively each of which kept $48 \mathrm{~h}$ on a shaker. For each of the extract filtration was done by filter paper at $24 \mathrm{~h}$ interval in the same flask followed by evaporation until the extract was left as a scum. The extracts were removed to glass vials and preserved in a refrigerator at $4^{\circ} \mathrm{C}$ with proper labeling.

\subsection{Collection and culture of test insects}

The test insects $T$. castaneum and $C$. chinensis of same age (3-5 days) used in this investigation were collected from the stock cultures of the Crop Protection Laboratory, Department of Zoology, University of Rajshahi, Bangladesh. A. salina nauplii were emerged from the cysts released in a container of salty water and were used within a period of $24-30 \mathrm{~h}$ of age.

\subsection{Repellent activity}

The method of repellency test used in this investigation was adopted from the method (No. 3) of McDonald et al. [18]. The average of the counts was converted to percent repulsion $(\mathrm{PR})$ using the formula, $P R=(N c-5) \times 20$; where, $\mathrm{Nc}$ is the average hourly observation of insects on the untreated half of the disc $[19,20]$. A general concentration for each of the extracts (Pet. ether, $\mathrm{CHCl}_{3}$ and $\mathrm{CH}_{3} \mathrm{OH}$ ) was selected as stock dose for repellency applied against $T$. castaneum adults and other successive doses were prepared by serial dilution to give $0.1571,0.0785,0.0392,0.0196$ and $0.0098 \mathrm{mg} / \mathrm{cm}^{2}$. For the application of $T$. castaneum half filter paper discs (Whatman No. 40, $9 \mathrm{~cm}$ diam.) were prepared and selected doses of all the extracts separately applied onto each of the half-disc and allowed to dry out as exposed in the air for $20 \mathrm{~min}$ (approximately). Each treated halfdisc was then attached lengthwise, edge-to-edge, to a control half-disc with adhesive tape and placed in a Petri dish $(9 \mathrm{~cm}$ diam.). For each of the test samples three replicates were maintained. Being volatile the solvent was evaporated out within a few minutes. Then ten insects were released in the middle of each of the filter paper circles. Repellency was observed for one-hour interval and up to five successive hours of exposure, just by counting the number of insects from the non-treated part of the filter paper spread on the floor of the $90 \mathrm{~mm}$ Petri dish. The values in the recorded data were then calculated for percent repellency, which was again developed by arcsine transformation for the calculation of analysis of variance (ANOVA).

\subsection{Dose-mortality test}

\subsubsection{Dose-mortality tests on T. castaneum}

For insecticidal activity test each of the three extracts was dissolved in its solvent of extraction at different concentrations to go through the Ad Hoc experiment to get 
considerable mortality and that were considered as doses. The concentrations used in this experiment were 2.037, 1.782, 1.527, 1.273 and $1.032 \mathrm{mg} / \mathrm{cm}^{2}$ for Pet. ether extract; 2.291, 2.164, 2.037, 1.909 and $1.782 \mathrm{mg} / \mathrm{cm}^{2}$ or $\mathrm{CHCl}_{3}$ extract; and 2.419, 2.291, 2.164, 2.037 and $1.909 \mathrm{mg} / \mathrm{cm}^{2}$ for the $\mathrm{CH}_{3} \mathrm{OH}$ extract. For each of the doses $1 \mathrm{~mL}$ was dropped on a Petri dish $(50 \mathrm{~mm})$ in such a way that it made a uniform film over the Petri dish. Then the Petri dishes were air-dried leaving the extract on it. The actual extract present in $1 \mathrm{ml}$ mixture was calculated just dividing the value by the area of the Petri dish and thus the dose per square centimeter was calculated. After drying 10 beetles (3-5 day old) were released in each of the Petri dishes in 3 replicates. A control batch was also maintained with the same number of insects after preparing the Petri dish by applying and evaporating the solvent only. The treated beetles were placed in an incubator at the same temperature as reared in stock cultures and the mortality of the beetles was counted after $0.5,6,12,18$ and $24 \mathrm{~h}$ of exposure.

\subsubsection{Dose-mortality tests on C. chinensis}

The concentrations used in this experiment were $0.763,0.612,0.509,0.407$ and 0.305 $\mathrm{mg} / \mathrm{cm}^{2}$ for Pet. ether extract; $1.018,0.763,0.509,0.254$, and $0.152 \mathrm{mg} / \mathrm{cm}^{2}$ for $\mathrm{CHCl}_{3}$ and $\mathrm{CH}_{3} \mathrm{OH}$ extracts. For each dose $1 \mathrm{~mL}$ was dropped on a Petri dish $(50 \mathrm{~mm})$ where a few pulse grains were kept. Then the Petri dishes were air-dried leaving the extract on it. After drying 10 beetles (3-5 days old) were released in each of the Petri dishes and the whole experiment was set in 3 replicates. A control batch was also maintained with the same number of insects after preparing the Petri dish in the same way as done for T. castaneum with only solvent. The mortality of the beetles was counted after $6,12,18,24,30$ and $36 \mathrm{~h}$ of exposure.

\subsubsection{Brine shrimp lethality test}

Brine shrimp lethality bioassay is a recent development in the bioassay techniques for the detection of biological activity like cytotoxicity, as well as, a wide range of pharmacological activities (e.g. anticancer, antiviral, pesticidal, anti-AIDS, etc.) of the compounds. To carry on toxicity tests nauplii were grown from its marketed cysts. Test samples at different concentrations considered as doses were prepared in test tubes by addition of calculated amount of DMSO (dimethylsulfoxide) to make them hydrophilic before adding half of the required amount of water in each. Then additional amount of water was added to fill the pre-marked test-tubes with the help of a pipette. The nauplii were counted by visual inspection and were released in test-tubes containing $10 \mathrm{~mL}$ of water and the test-tubes along with a control batch was left for $30 \mathrm{~h}$. Observation of mortality was made after $6,12,18,24,30$ and $36 \mathrm{~h}$ of exposure. Doses for all three extracts Pet. ether, $\mathrm{CHCl}_{3}, \mathrm{CH}_{3} \mathrm{OH}$ were 200, 400 and $800 \mathrm{ppm}$. 


\subsubsection{Statistical analysis}

The mortality (\%) was corrected using Abbott's formula, $P r=(P o-P c) /(100-P c) \times 100$; Here, $P r=$ corrected mortality $(\%), P o=$ observed mortality $(\%)$ and $P c=$ mortality in the control $(\%)$. The data were then subjected to probit analysis $[21,22]$.

\section{Results}

\subsection{Repellent activity of T. castaneum}

The Pet. ether and $\mathrm{CHCl}_{3}$ extracts found to be active against $T$. castaneum adults with repellency at $1 \%$ and $5 \%$ levels of significance $* *=(P<0.01)$ and $*=(\mathrm{P}<0.05)$. While, the methanol extract of $C$. viscosa did not show any activity at all (Table 1).

Table 1. ANOVA results of the repellency of T. castaneum by the Pet. ether, $\mathrm{CHCl}_{3}$ and $\mathrm{CH}_{3} \mathrm{OH}$ extracts of $C$. viscosa (whole Plant).

\begin{tabular}{|c|c|c|c|c|c|c|c|c|}
\hline \multirow{2}{*}{$\begin{array}{l}\text { Test } \\
\text { organism }\end{array}$} & \multirow{2}{*}{$\begin{array}{l}\text { Extracts } \\
\text { of } \quad C \text {. } \\
\text { viscosa }\end{array}$} & \multicolumn{3}{|c|}{ Sources of variation } & \multicolumn{2}{|c|}{$\begin{array}{l}\text { F-ratio with level of } \\
\text { significance }\end{array}$} & \multicolumn{2}{|l|}{ P-value } \\
\hline & & $\begin{array}{l}\text { Between } \\
\text { doses }\end{array}$ & $\begin{array}{l}\text { Between } \\
\text { time } \\
\text { interval }\end{array}$ & Error & $\begin{array}{l}\text { Between } \\
\text { doses }\end{array}$ & $\begin{array}{l}\text { Between } \\
\text { time } \\
\text { interval }\end{array}$ & $\begin{array}{l}\text { Between } \\
\text { doses }\end{array}$ & $\begin{array}{l}\text { Between } \\
\text { time } \\
\text { interval }\end{array}$ \\
\hline \multirow{3}{*}{$\begin{array}{l}T . \\
\text { castaneum }\end{array}$} & $\begin{array}{l}\text { Pet. } \\
\text { ether }\end{array}$ & 2751.967 & 459.015 & 16 & $48.517 * *$ & 8.092 & $9.5 \mathrm{E}-09$ & 0.0009 \\
\hline & $\mathrm{CHCl}_{3}$ & 1316.798 & 753.716 & 16 & $12.698 *$ & 7.268 & $\begin{array}{l}7.68 \mathrm{E}- \\
05\end{array}$ & 0.0015 \\
\hline & $\mathrm{CH}_{3} \mathrm{OH}$ & 188.272 & 2865.556 & 16 & 0.290 & 4.410 & 0.8803 & 0.0137 \\
\hline
\end{tabular}

\subsection{Dose mortality effects on $T$. castaneum and C. chinensis}

The results of the dose mortality assays of Pet. ether, $\mathrm{CHCl}_{3}$ and $\mathrm{CH}_{3} \mathrm{OH}$ extracts of $C$. viscosa against adult beetles of $T$. castaneum are represented in Table 2 . The $\mathrm{LD}_{50}$ values were $2.380,2.188,1.867,1.658$ and $1.429 \mathrm{mg} / \mathrm{cm}^{2} ; 4.950,2.906,2.664,2.658$ and 2.609 $\mathrm{mg} / \mathrm{cm}^{2}$; and 4.950, 2.791, 2.609, 2.552 and $2.474 \mathrm{mg} / \mathrm{cm}^{2}$ all after $0.5,6,12,18$ and $24 \mathrm{~h}$ of exposure respectively. Against $C$. chinensis Pet. ether, $\mathrm{CHCl}_{3}$ and $\mathrm{CH}_{3} \mathrm{OH}$ extracts are represented in Table 3.The $\mathrm{LD}_{50}$ values were 0.781, 0.670, 0.642, 0.614, 0.560 and 0.494 $\mathrm{mg} / \mathrm{cm}^{2} ; 1.964,1.050,0.867,0.725,0.635$ and $0.590 \mathrm{mg} / \mathrm{cm}^{2}$; and $2.631,1.851,1.471$, $1.703,1.524$ and $1.457 \mathrm{mg} / \mathrm{cm}^{2}$ all after $6,12,18,24,30$ and $36 \mathrm{~h}$ of exposure respectively. According to the intensity of activity the extracts could be arranged in a descending order of Pet. ether $>\mathrm{CH}_{3} \mathrm{OH}>\mathrm{CHCl}_{3}$ extracts in case of T. castaneum; and against $C$. chinensis Pet. ether $>\mathrm{CHCl}_{3}>\mathrm{CH}_{3} \mathrm{OH}$ extracts as well (Tables 2, 3). 
Table 2. $\mathrm{LD}_{50}$ values of Pet. ether, $\mathrm{CHCl}_{3}$ and $\mathrm{CH}_{3} \mathrm{OH}$ extracts of $C$. viscosa against $T$. castaneum.

\begin{tabular}{llllll}
\hline \multirow{2}{*}{ Extracts } & \multicolumn{5}{c}{$\mathrm{LD}_{50}$ at different exposures $\left(\mathrm{mg} / \mathrm{cm}^{2}\right)$} \\
\cline { 2 - 6 } & $0.5 \mathrm{~h}$ & $6 \mathrm{~h}$ & $12 \mathrm{~h}$ & $18 \mathrm{~h}$ & $24 \mathrm{~h}$ \\
\hline Pet. ehter & 2.3807 & 2.1883 & 1.8677 & 1.6589 & 1.4292 \\
$\mathrm{CHCl}_{3}$ & 4.9502 & 2.9060 & 2.6643 & 2.6586 & 2.6098 \\
$\mathrm{CH}_{3} \mathrm{OH}$ & 4.9502 & 2.7914 & 2.6098 & 2.5528 & 2.4747 \\
\hline
\end{tabular}

Table 3. $\mathrm{LD}_{50}$ values of Pet. ether, $\mathrm{CHCl}_{3}$ and $\mathrm{CH}_{3} \mathrm{OH}$ extracts of $C$. viscosa against $C$. chinensis

\begin{tabular}{lllllll}
\hline \multirow{2}{*}{ Extracts } & \multicolumn{6}{c}{$\mathrm{LD}_{50}$ at different exposures $\left(\mathrm{mg} / \mathrm{cm}^{2}\right)$} \\
\cline { 2 - 7 } & $6 \mathrm{~h}$ & $12 \mathrm{~h}$ & $18 \mathrm{~h}$ & $24 \mathrm{~h}$ & $30 \mathrm{~h}$ & $36 \mathrm{~h}$ \\
\hline Pet. ether & 0.7817 & 0.6701 & 0.6420 & 0.6140 & 0.5607 & 0.4942 \\
$\mathrm{CHCl}_{3}$ & 1.9647 & 1.0501 & 0.8678 & 0.7252 & 0.6350 & 0.5907 \\
$\mathrm{CH}_{3} \mathrm{OH}$ & 2.6315 & 1.8518 & 1.4712 & 1.7033 & 1.5248 & 1.4578 \\
\hline
\end{tabular}

\subsection{Lethal effect of A. salina}

Pet. ether, $\mathrm{CHCl}_{3}, \mathrm{CH}_{3} \mathrm{OH}$ extracts offered cytotoxicity and gave $\mathrm{LC}_{50}$ values 3071.54 , 1741.01, 1122.06 and 918.11 ppm; 101.534, 29.366, 18.078 and 3.103 ppm; and 73.368, $38.989,24.735$ and $23.299 \mathrm{ppm}$ after 12, 18, 24 and $30 \mathrm{~h}$ of exposure respectively. Against $A$. salina the extracts could be arranged in a descending order of $\mathrm{CH}_{3} \mathrm{OH}>\mathrm{CHCl}_{3}$ $>$ Pet. ether extracts (Table 4).

Table 4. $\mathrm{LC}_{50}$ values of Pet. ether, $\mathrm{CHCl}_{3}$ and $\mathrm{CH}_{3} \mathrm{OH}$ extracts of $C$. viscosa against $A$. salina.

\begin{tabular}{lllll}
\hline \multirow{2}{*}{ Extracts } & \multicolumn{4}{c}{$\mathrm{LC}_{50}$ at different exposures $(\mathrm{ppm})$} \\
\cline { 2 - 5 } & $12 \mathrm{~h}$ & $18 \mathrm{~h}$ & $24 \mathrm{~h}$ & $30 \mathrm{~h}$ \\
\hline Pet. ether & 3071.548 & 1741.013 & 1122.066 & 918.115 \\
$\mathrm{CHCl}_{3}$ & 101.534 & 29.366 & 18.078 & 3.103 \\
$\mathrm{CH}_{3} \mathrm{OH}$ & 73.368 & 38.989 & 24.735 & 23.299 \\
\hline
\end{tabular}

\section{Discussion}

The aforementioned data receive supports from the previous researchers' findings. A recent study has been conducted on the contact toxicity effects of three Cleome species's methanol extracts against Sitophilus oryzae and found much promising toxicity with recording the least median lethal concentration $\left(\mathrm{LC}_{50}\right)$. This work also confirmed ovicidal activities and ovipositon deterrent of $C$. viscosa against $S$. oryzae [23]. Another study has also been found to show antifeedant and chronic toxic properties of seed extracts of $C$. viscosa against Hispa armigera [24]. Moreover, another investigation on toxicity on albino rats has been stipulated the methanolic extracts of Cleome viscosa to be significant in wound healing activity as evidenced by the reduction in the number of days required, and the wound contraction compared to the standard [25]. C. viscosa seed oil has peripheral analgesic and antiemetic activities [26]. Potent contact and stomach activity of C. viscosa extracts against first instars of Clavigralla tomentosicollis also confirmed the insecticidal activity of this plant ${ }^{[27]}$. Its related species Cleome rupicola plant extract is 
applied traditionally as eye-drops [28], Cleome Arabica, a desert plant widely distributed in the North Africa is used as a sedative for rheumatic and abdominal aches ${ }^{[29]}$ and $C$. gynandra is used to relieve pain, cure skin disease on leprosy, earache [30]. Acetone, methanol, benzene and hexane extracts of $C$. viscosa were found active against larvicidal and ovicidal activity in Aedes aegypti [31]. This present investigation has also supported with the result of another research, where $C$. viscosa offered promising insecticidal activity against Callosobruchus chinensis. Various solvents viz.; acetone, chloroform, petroleum ether, methanol, hexane, and water extracts of $C$. viscosa have shown much insecticidal potential as $\mathrm{LD}_{50}$ obtained in each was very low. These also have significantly repelled large number of insects at a very low dose [32].

\section{Conclusion}

After analyses of data it is revealed that extracts of $C$. viscosa possesses insect killing properties, along with repellent and cytotoxic activities. Recently, the use of environment friendly and biodegradable natural insecticides of plant origin have received renewed attention because they are rich with bioactive compounds active against specific target insects. So, further investigation is needed to isolate the exact compound which could be a great lead of pharmaceutical and agricultural potentials.

\section{Acknowledgment}

The authors are grateful to the University Grants Commission (UGC) of Bangladesh. They would like to extend their gratefulness to the Chairman, Department of Zoology, Rajshahi University, for providing laboratory facilities.

\section{References}

1. H. O. Edeoga, G. Omosun, G. G. E. Osuagwu, B. O. Mbaebie, and B. A. Madu, AmericanEurasian J. Sci. Res. 4(3), 124 (2009).

2. K. R. Kirtikar, B. D. Basu., Indian Medicinal Plants, $2^{\text {nd }}$ Edition (International Books Distribution, Dehradun, India, 1987) 1, 181.

3. T. Pullaiah, Medicinal plants in India, Vol. I, (Regency Publications, New Delhi, 2003) pp. 168.

4. S. Arivoli, and T. Samuel, World J. Zool. 7(1), 6 (2012).

5. R. K. Maikhuri, R. L. Semwal, K. S. Rao, S. Nautiyal, and K. G. Saxena, Econ. Bot. 54(2), 150 (2000). https://doi.org/10.1007/BF02907819

6. H. Singh, A. Mishra, and A. K. Mishra, Pharmacogn. J. 7(6), 326 (2015). https://doi.org/10.5530/pj.2015.6.1

7. J. Anburaj, C. R. Singh, T. Kuberan, C. Sundaravadivelan, and P. Kumar, Res. J. Pharm. Biol. Chem. Sci. 2(2), 576 (2011).

8. K. Hussain, M. F. Nisar, A. Majeed, K. Nawaz, and K. H. Bhatti, Ethnobot. Leaflets. 14, 807 (2010).

9. E. H. Smith and R. C. Whitman, Field Guide to Structural Pests. National Pest Management Association (Dunn Loring, VA, 1992). 
10. F. H. Chittenden, Some Insects Injurious to Stored Grains and Their Habits and Control (McGraw Hill Book Company, New York, 1987) pp: 925.

11. N. E. Good, USDA Technical Bull. 5, 27 (1936).

12. T. Srinivasan and C. Durairaj, ICFAI J. Life Sci. 2(4), 42 (2008).

13. S. Yanagi, Y. Saeki, and M. Tuda, Entomologia Experimentalis et Applicata 148, 182 (2013). https://doi.org/10.1111/eea.12088

14. A. Asem, N. Rastegar-Pouyani, and P. Rios-Escalante, Lat. Am. J. Aquat. Res. 38(3), 501 (2010).

15. D. Martin, Rotifers and Artemia for Marine Aquaculture: A Training Guide (University of Tasmania, 1996).

16. D. Mioara, Balneo-Res. J. 2(4), 119 (2011).

17. E. Sara, "Artemia salina (L)", Animal Diversity Web (University of Michigan, 2012).

18. L. L. McDonald, R. H. Guy, and R. D. Speirs Preliminary Evaluation of New Candidate Materials as Toxicants Repellents and Attractants against Stored-product Insects (Marketing Research Report, Agricultural Research Service, US Department of Agriculture, Washington DC, 1970) 882.

19. F. A. Talukder and P. E. Howse, J. Chem. Ecol. 19, 2463 (1993). https://doi.org/10.1007/BF00980683

20. F. A. Talukder and P. E. Howse, J. Stored. Prod. Res. 31(1), 55 (1995). https://doi.org/10.1016/0022-474X(94)00036-S

21. D. J. Finney, Probit Analysis: A Statistical Treatment of the Sigmoid Response Curve (Cambridge University Press. London, 1947) pp. 333.

22. J. R. Busvine, A Critical Review of the Techniques for Testing Insecticides (Commonwealth Agricultural Buereux, London, 1971) pp. 345.

23. S. Somboon and S. Pimsamarn, Agr. Sci. J. 37(5), 232 (2006).

24. G. Sivaraman, M. G. Paulraj, S. Ignacimuthu, and N. A. Al-Dhabi, Int. J. Pure Appl. Zool. 2(3), 211 (2014).

25. T. Panduraju, B. Parvathi, M. Rammohan, and C. S. Reddy, Hygeia J. D. Med. 3(1), 41 (2011).

26. S. Ahmed, M. Sultana, M. M. U. Hasan, and I. Azhar, Pak. J. Bot. 43, 119 (2011).

27. R. K. Upadhyay, Int. J. Green Pharm. 9(2), 71 (2015). https://doi.org/10.4103/0973$\underline{8258.155050}$

28. A. G. Shahina, M. Ahmed, and A. A. Sabahi, Econ. Bot. 47, 89 (1993). https://doi.org/10.1007/BF02862209

29. S. Facciola, Cornucopia, A Source Book of Edible Plants (1870 Sunrise Drive, Vista, CA: Kampong Publications, 1990).

30. J. Gardiner and L. J. Brace, Provisional List of the Plants of the Bahama Islands - Proc. Acad. Natl. Sci. Phila. 41, 349 (1889).

31. K. Krishnappa and K. Elumalai, Eur. Rev. Med. Pharmacol. Sci. 17, 1273 (2013).

32. R. K. Upadhyay and N. Yadav, Int. J. Chem. Biol. Sci. 1, 91 (2012). 